\title{
Common Writing Errors Among EFL Students at Dhofar University in Oman: An Analytical Study
}

\author{
Yasser Muhammad Naguib Sabtan ${ }^{1,2}$ \& Abdelkader Mohamed Abdelkader Elsayed ${ }^{1,3}$ \\ ${ }^{1}$ College of Arts and Applied Sciences, Dhofar University, Salalah, Oman \\ ${ }^{2}$ Faculty of Languages and Translation, Al-Azhar University, Cairo, Egypt \\ ${ }^{3}$ College of Education, Benha University, Benha, Egypt \\ Correspondence: Yasser Muhammad Naguib Sabtan, College of Arts and Applied Sciences, Dhofar University, \\ Salalah, PO Box: 2509, Postal Code: 211, Oman. E-mail: ysabtan@du.edu.om
}

Received: January 10, 2019 Accepted: February 8, 2019 Online Published: March 7, 2019

doi:10.5539/ijel.v9n2p402 URL: https://doi.org/10.5539/ijel.v9n2p402

\begin{abstract}
The present study aims to analyze the common writing errors made by EFL students at Dhofar University in the Sultanate of Oman. The study included 93 first-year students enrolled in a university requirement course. The students' written English essays were collected to carry out the analysis. A number of errors in the students' essays are identified and classified into various types. The results of the analysis of the students' writing samples show that the common errors of EFL students at Dhofar University are basically related to spelling and grammar. Spelling and grammatical errors are classified into different types, with a frequency count for each type of error. Grammatical errors account for the biggest number of errors which are distributed on eight different types. These types are listed in order based on their frequency as follows: (1) verb tense and form, (2) plurality (3) subject-verb agreement (4) prepositions (5) part-of-speech (6) word order (7) articles (8) adjective form. Spelling errors, on the other hand, are classified into four types which are listed in order as follows: (1) omission (2) substitution (3) insertion (4) transposition. Based on these results, a number of recommendations for treatment of writing errors are suggested.
\end{abstract}

Keywords: EFL, error analysis, essays, Omani students, writing errors

\section{Introduction}

There has been recently a growing interest in the field of error analysis. Researchers interested in errors analysis have observed that error analysis is very important for both learners and teachers. According to Alhaysony (2012), error analysis is advantageous for both learners and teachers. For learners, it is needed to show them the aspects of language that are difficult for them. As for teachers, it provides them with information about the students' errors. This, in turn, helps the teachers in a number of ways. Firstly, they work on correcting their students' errors. Secondly, this consequently improves their teaching methods and thirdly they could focus on those areas that need reinforcement.

In fact, learning a foreign language always involves a number of challenges, especially in the initial phases of learning, where EFL learners make linguistic errors at different levels: phonological, syntactic and semantic (Rimbar, 2017). These errors, as pointed out by James (2013), are a by-product of learning the language, and they can be used to indicate at which phase of learning the learners are. Furthermore, the learners' errors, as indicated by Brown (2007), negatively affect the quality of language among students. Similarly, Al-Busaidi and Al-Saqqaf (2015) maintain that the students' errors often affect their intelligibility in writing and speaking.

Writing, which is the focus of this paper, is one of the main skills of language usage. Writing is an essential skill in student's academic study in all universities, as it is needed for writing essays, writing reports, taking notes and carrying out research (Ulijn \& Strother, 1995). Therefore, writing has always been an essential component of English language teaching in the Arab Higher Education Institutions (Khuwaileh \& Al Shoumali, 2000).

It is, thus, important to shed light on the common errors that second language learners make in their writing and explore the reasons behind such errors to identify them in a way to find the appropriate remedy for them. Accordingly, in this paper the authors investigate the common writing errors which EFL students at Dhofar University make. The study is focused on classifying such errors into different types and discussing the reasons 
behind each type of error.

This paper proceeds as follows. The following section presents the research questions. Section three explains the limits of the study. In section four the researchers review the previous studies on writing errors made by EFL students. Section five introduces the methods used in the current study and the data collection. In section six the results are presented and discussed. Finally, section seven concludes the paper with suggestions for further research.

\section{Research Questions}

The current study attempts to answer the following research questions:

a) What types of errors are common in the writings of Omani EFL students at Dhofar University?

b) Which of these types are most prevalent?

c) What are the possible remedies for writing errors?

\section{Limits of the Study}

The limits of the study are the following:

1) Learners: First year students at Dhofar University (DU), which is an important higher education institution in the Sultanate of Oman.

2) Course: ENGL 101 (Basic Academic English) is a university requirement course at DU. This course was chosen because it is a university requirement for all DU students with different specializations (e.g., business, law, arts and engineering). This, in turn, is expected to enrich the data with writing errors produced by students from different colleges. The study's samples were collected from the students' writings in this course in the academic year 2016/2017.

3) Writing errors: The study focuses on spelling and grammatical errors because they have been found to be the most common errors among DU EFL students.

\section{Literature Review}

Learning a second/foreign language is often challenging for learners as they construct some patterns or rules in the language they are learning according to which they pronounce and spell the words. A second language has patterns different from their mother tongue (or native language) which creates problems for learning another language. The patterns of a learner's first language become part of the linguistic instinct of that learner (Kocatepe, 2017).

Brown (2007) points out that the learners' errors negatively affect the quality of language among students, as he states that the quality of the language of many students has been affected by errors that were not tackled on time, probably due to the lack of awareness. Such awareness is connected to identifying errors that are produced when communication is taking place.

In the literature on error analysis, there are many definitions of error. Norrish (1983, p. 7) defines 'an error' as "a systematic deviation that happens when a learner has not learnt something, and consistently gets it wrong." He points out that normally EFL learners make systematic errors because they have not learnt the correct form. In other words, the error is the kind of mistakes in which the speaker or writer violates the rules of language (Naif $\&$ Saad, 2017). Therefore, the mistakes in the speaking or writing that occur regularly are called errors, and may be due to the student's lack of knowledge of the nature of language and its rules.

As far as Arabic-speaking students are concerned, the sources of the errors they make in their writings can be described as interlingual or intralingual. According to Alhaysony (2012), interlingual errors are caused by interference from the native language or mother tongue (L1); however, intralingual errors have nothing to do with L1 interference, but are due to faulty or partial learning of L2 (Qaid \& Ramamoorthy, 2011).

In this context, Al Jayousi (2011) identified four different types of interlingual errors:

1) Vocalic transfer: In this category, Arab students show lack of the knowledge of how to use the correct vowel in the appropriate manner. The learners tend to use vowels abundantly without considering the rules for vowel use or the basic knowledge of the big differences between Arabic and English. For example, instead of writing "much", the majority of the Arab students wrote *"mach".

2) Consonant replacement: Arab learners tend to substitute letters with an available equivalent or counterpart. For instance, Arabic does not have the voiceless bilabial plosive / $\mathrm{p} /$ or a written form for it, so many Arab students replaced it with the voiced bilabial plosive / $b$ / that is available in Arabic orthography. In many cases, 
Arab learners wrote * "groubs" instead of "groups".

3) Epenthesis: Since Arabic has very few consonant clusters, students tended to use a vowel to break up a cluster of consonants. For instance, "tempting" was written as * "tempiting" by many Arabic-speaking students.

4) Nativization: Arabic-speaking students write or spell words in the way borrowings from English are pronounced and spelled in Arabic, e.g., *"Amreca" is written instead of "America".

As for intralingual errors, Murad and Khalil (2015) point out that intralingual errors come from the second language (L2), and are represented by a number of phenomena. Thus, Arab learners of English, for instance, tend to use simple tenses instead of compound tenses. They also avoid difficult structures such as the passive voice. In addition, they continue to make errors in missing the "s" with the third person in the present tense as in *"she play tennis" and they also make errors in forming the irregular verbs in the past tense by applying the same formation for the regular verbs, Thus, instead of using "gave" as the irregular form in the past they use *"gived".

Therefore, the linguistic error can be defined as any language version issued by a student that violates the grammar of the language and is not approved by the teacher, and this is the focus of the current study.

According to James (2013), error analysis is very important in foreign language learning, as the study of errors provides the teacher with evidence of how the foreign language is acquired, as well as the strategies used by the learners to acquire it. Moreover, conducting a systematic analysis of learners' errors could help indicate their needs for learning the language, so teaching can respond in a better way and learning occurs at a faster pace.

Many studies have been conducted to analyze the EFL learners' writing errors, including Arab EFL learners. Abu Rass (2015) shed light on the problems facing Palestinian EFL students in developing well-written paragraphs in the English language. The results showed that EFL students faced a number of writing problems, particularly in the following three areas: paragraph structure, sentence structure, content and organization. She pointed out that such problems were due to the fact that the EFL students transferred the writing style of their mother tongue to the English language.

Another study conducted by Younes and Albalawi (2015) investigated the types of common errors among students of Tabuk University. The findings of the study indicated that most language errors were basically of grammatical nature (related to the use of articles, prepositions, tenses and subject-verb agreement), punctuation errors (e.g., the absence, addition or misuse or punctuation marks) and spelling errors (including such types as the addition, substitution, omission, segmentation and disordering).

In the same vein, Sawalmeh (2013) explored the errors made by 32 Saudi learners of English at University of Ha'il. The findings showed that the students in this study made a number of common errors. These errors were classified into different types related to grammar and spelling, but most of them are related to grammar (including articles, word order, verb tense, subject-verb agreement, prepositions and plural form).

Some EFL researchers have focused on investigating one aspect of common writing errors. So, for instance, Al-Busaidi and Al-Saqqaf (2015) conducted a study to investigate problems that Arab learners face in spelling English vowels. The study concluded that the Arab students face great difficulties in spelling rhyming words (e.g. "role" and "rule", "heat" and "hit", "fill" and "full"). In addition, the students were not able to distinguish between long and short vowels. For instance, nearly all the students spelled the word "hit" as "heat". Similarly, Al Harrasi (2012) investigated the most common spelling errors patterns among Omani learners in a second-cycle school (grade 6 female students). The errors found in this study are in line with the categories suggested by Cook (1999), which are insertion, omission, substitution and transposition. This is also in line with the results of the present study.

Hourani (2008) investigated the common grammatical errors in the English writings of Emirati secondary level male students. The most common grammatical errors included verb tense and form, passivization, subject-verb agreement, word order, articles, plurality, auxiliaries and prepositions.

Also, another study was carried out by Salem (2007) who discussed the errors in the writings of students majoring in English at Al-Azhar University in Egypt. In the study he pointed out that most of the students had problems with regard to vocabulary, idioms and rhetorical strategies. Their errors were typical of advanced students and so the results of the study cannot be applied to other lower grade students or students majoring in other subjects.

Hasbún (2007) carried out a study with 159 EFL university students for which eight different writing samples from each participant were analyzed. Such samples were evaluated and errors were classified according to an error taxonomy; the most common errors were classified into eight categories: vocabulary, prepositions, 
pronouns, plurals, word order, agreement, verb forms, and spelling. This study shows a commonality with the present study, as most of these errors are identified in the current population.

It is thus obvious that the previous studies have focused on investigating the common errors in learning English, since identifying such errors is an important part of the learning process. Similarly, the current study aims at analyzing the common writing errors among EFL students at Dhofar University in Oman. These errors are basically related to spelling and grammar, since they have been found to be the most common among Omani EFL learners. Thus, the common error in the present study refers to any linguistic deviation from the rule for spelling and grammar.

\section{Methods}

This section discusses the research methods that are used in the current study, including the study procedures, participants and data collection and analysis.

\subsection{The Study Procedures}

This study used the descriptive analytical approach through using a number of procedures which are outlined as follows:

1) Identifying the common writing errors made by Omani learners of English through analyzing the students' writing samples.

2) Classifying the errors into different linguistic types.

3) Exploring the reasons behind these types of errors.

4) Computing the frequency of such errors.

5) Suggesting possible remedies for treatment of writing errors

\subsection{Participants}

A total of 93 EFL first-year students (males and females) participated in the study. Those students, whose native language is Arabic, were enrolled in a university requirement course which is called Basic Academic English 101 (ENGL 101) at Dhofar University in Oman. ENGL 101 is a three-credit hour course for one full semester (17 weeks), which all university students have to pass to move to a higher-level course.

\subsection{Instruments}

\subsubsection{Data Collection}

The participants were given 50 minutes to write a well-organized compare and contrast essay on one of three different topics, as part of the semester final exam. They were asked to write approximately 200-250 words. The given topics were the following:

1) Life in a big city and a small town

2) Public and private transport

3) Home-made food and restaurant food

\subsubsection{Data Analysis}

The analysis of essays is based on Corder's (1967) method on error analysis. This method was chosen for carrying out the analysis as it contains a number of steps that account for a comprehensive diagnosis of students' errors. The method consists of three steps in order: (1) collection of sample errors (2) identification of errors and (3) description of such errors. This paper focuses on the errors that are basically related to spelling and grammar, as they have been found to be the most common among the EFL students in the current study. The lexical errors (e.g., vocabulary, word choice and collocations) are not the focus of this paper. The researchers classified the common errors in a corpus containing 93 writing samples into different types of linguistic errors. Moreover, the researchers computed the frequency of each error type and their percentages of the total as well as describing these errors, showing their sources (or causes).

\section{Results and Discussion}

This section presents the findings of the study and a detailed analysis of the common writing errors most frequently made by 93 first-year EFL students at Dhofar University. The first and second research questions raised in section two will be addressed in the following lines. The common writing errors are classified into two main types: spelling errors and grammatical errors. In the analysis the researchers sub-classify spelling errors into four different types (omission, substitution, insertion and transposition). These four categories correspond to 
Cook's (1999) classification. Most misspelled words contain one of these types of error. However, some misspelled words contain two or more spelling errors. Furthermore, the researchers sub-classify grammatical errors into eight different types (verb tense and form, plurality, subject-verb agreement, prepositions, part-of-speech, word order, articles and adjective form). The following table throws light on the types of common writing errors and the number of learners (or students) who made these errors along with the percentages for each type of error.

Table 1. Classification of writing errors and their frequency

\begin{tabular}{lll}
\hline Type of Error & No. of learners & Percentage (\%) \\
\hline Spelling Errors & & \\
Omission & 65 & $69.9 \%$ \\
Substitution & 57 & $61.3 \%$ \\
Insertion & 22 & $23.6 \%$ \\
Transposition & 6 & $6.45 \%$ \\
Grammatical Errors & & \\
Verb Tense and Form & 43 & $46.23 \%$ \\
Plurality & 29 & $31.18 \%$ \\
Subject-Verb Agreement & 23 & $24.73 \%$ \\
Prepositions & 18 & $19.35 \%$ \\
Part-of-speech & 17 & $18.27 \%$ \\
Word Order & 11 & $11.82 \%$ \\
Articles & 9 & $9.67 \%$ \\
Adjective Form & 6 & $6.45 \%$ \\
\hline
\end{tabular}

As can be seen in the previous table, grammatical errors account for the biggest number of errors, i.e. (a total of 156 errors distributed on eight different types). The table shows also that verb tense and form rank first among the common grammatical errors in the writings of Omani EFL students at Dhofar University. As for spelling errors, a total of 150 errors distributed on four different types have been made by Omani EFL learners. The highest number of spelling errors is concerned with omitting one letter in a word, whether in the medial or final position. The frequency for spelling and grammatical errors is best illustrated in Figures 1 and 2 respectively.

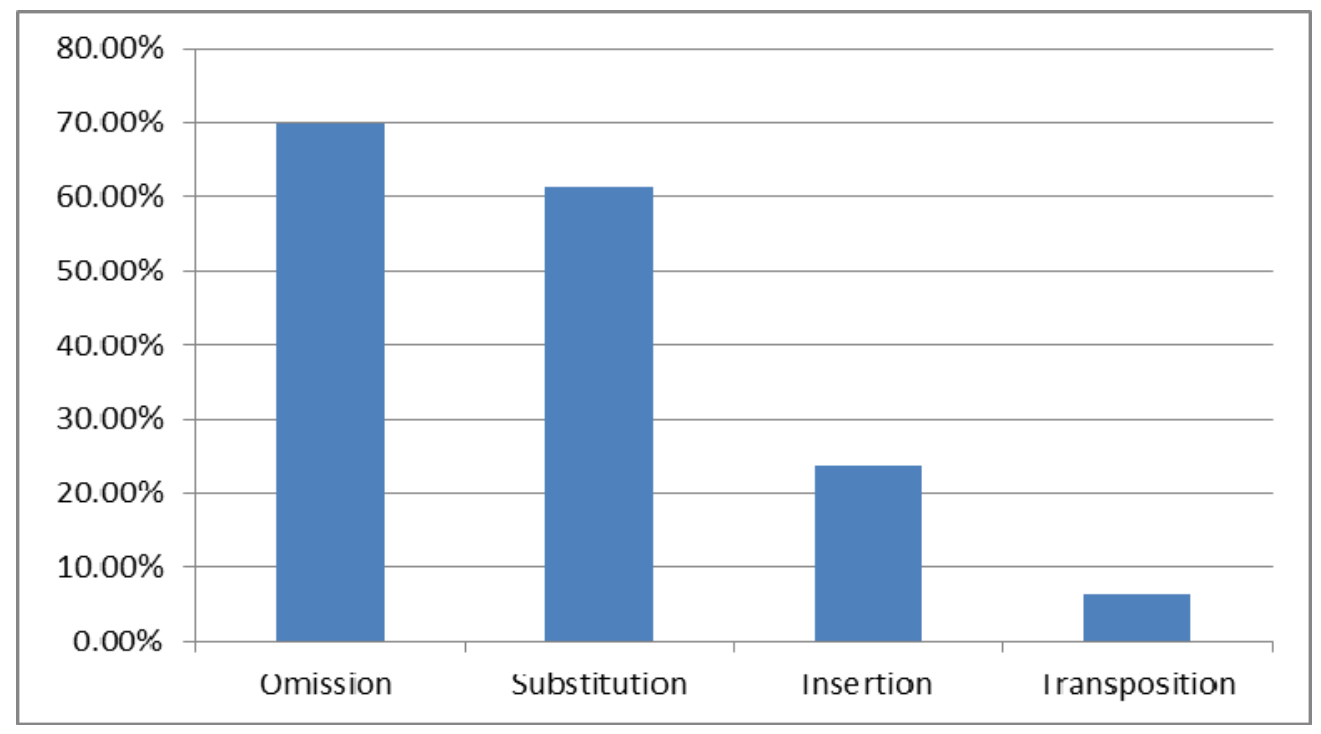

Figure 1. Frequency of spelling errors 


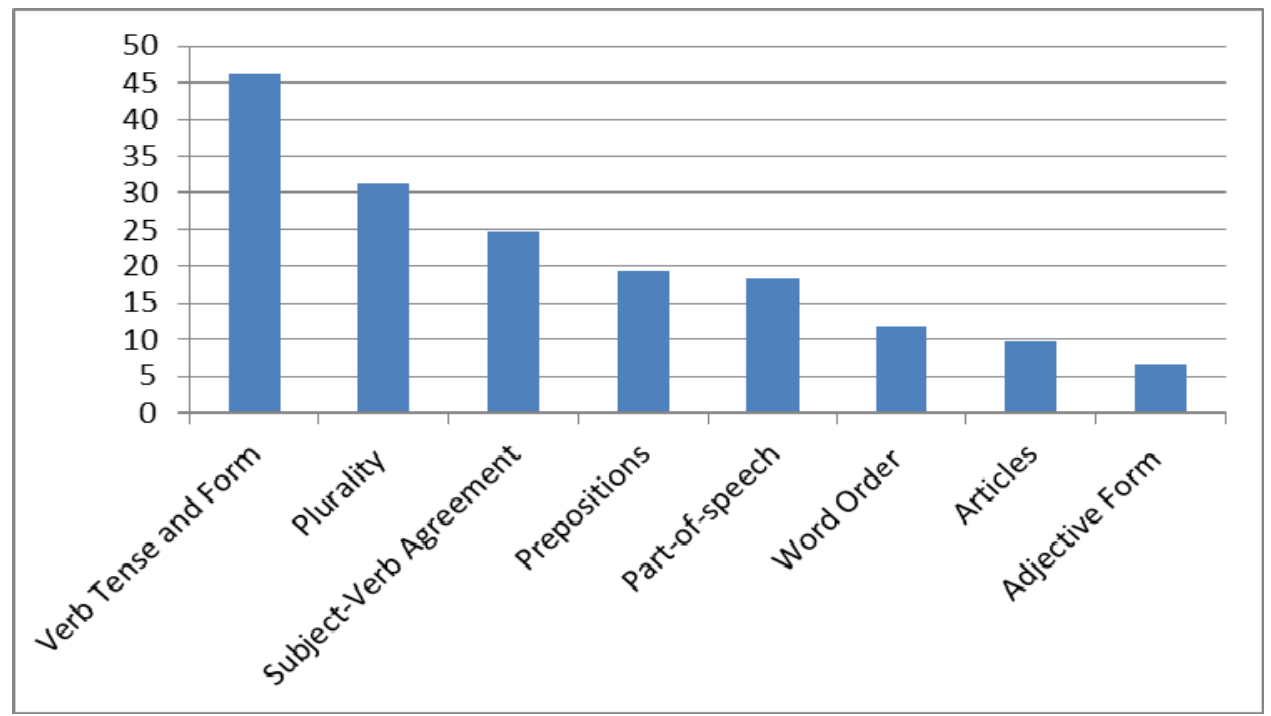

Figure 2. Frequency of grammatical errors

In the following subsections the researchers discuss each type of the writing errors (i.e., spelling errors and grammatical errors) with illustrative examples. In the first subsection the spelling errors with their different types are discussed. Second, the grammatical errors and their most common types are outlined.

\subsection{Spelling Errors}

In this section each type of the spelling errors is discussed with different examples to see the sources of these errors. Spelling, as pointed out by Kharma and Hajjaj (1997), constitutes a major difficulty for Arab students.

Table 2. Examples for different types of spelling errors

\begin{tabular}{llll}
\hline Error Type & Example Word & Correction & Explanation \\
\hline Omission & villag & village & The vowel "e" was deleted in the final position. \\
& helth & health & The vowel "a" was deleted in the medial position. \\
& resturant & restaurant & The vowel "a" was deleted in the medial position. \\
& quicly & quickly & The consonant "k" was deleted in the medial position. \\
& tourst & tourist & The vowel "i" was deleted in the medial position. \\
Substitution & thet & that & The vowel "e" was substituted for the vowel "a". \\
& thenk & think & The vowel "e" was substituted for the vowel "i". \\
& brefer & prefer & The consonant "b" was substituted for the consonant "p". \\
& reinfall & rainfall & The vowel "e" was substituted for the vowel "a". \\
& sity & city & The consonant "s" was substituted for the consonant "c". \\
Insertion & firstaly & firstly & The vowel "a" was inserted in the medial position. \\
& urbain & urban & The vowel "i" was inserted in the medial position. \\
& freedome & freedom & The vowel "e" was inserted in the final position. \\
& reastaurant & restaurant & The vowel "a" was inserted in the medial position. \\
& bothe & both & The vowel "e" was inserted in the final position. \\
thier & their & The vowels "e" and "ii" are misordered. \\
& freinds & friends & The vowels "i" and "e" are misordered. \\
& twon & town & The vowel "o" and the semi-vowel "w" are misordered. \\
\hline
\end{tabular}

\subsubsection{Errors of Omission}

As shown above, omission represents the first most frequent spelling error in the writing samples of the EFL learners. Most omission errors are concerned with the deletion of vowels in the medial and final position. As for consonants, it has been observed that students omit the consonant $[\mathrm{k}]$ when it follows the consonant [c] such as "quickly". When examining the sources of this error, the researchers agree with Alhaisoni et al. (2015) that such errors may be due to the students' attempt to construct a word based on their knowledge of grapheme-phoneme 
relationships. For example, they chose to omit the mute vowels that are not articulated, as the case with misspelling the word "health" as "helth". In addition, the participants have been found to omit the final [e] at the end of words, such as writing "villag" for "village". As regards consonant letters, the data show that the [k] letter is deleted when it is preceded by the letter [c], as in using "quicly" in place of "quickly". This is because the two letters [ck] are pronounced the same as any one of them separately.

It can be thus argued that the reason for the occurrence of most omission errors is interlingual, due to the differences between English and Arabic. According to Alhaisoni et al. (2015), the English language system is more complex than the Arabic language, as it lacks patterns in spelling and pronunciation. Arabic, however, is written the way it is pronounced. As the results show, omission is the most frequent type of spelling errors, where 65 students out of 93 students (i.e., $69.9 \%$ ) have made this error.

\subsubsection{Errors of Substitution}

The errors of substitution are the second most frequent type of spelling errors. It has been discovered that 57 students out of 93 students (i.e., $61.3 \%$ ) have made this substitution error. According to Cook (1997), learners tend to make two types of substitution errors: Vowel substitution and consonant substitution. It has been observed in the writing samples of students that substitution errors are the result of substituting vowels more frequently than consonants. Most vowel errors are concerned with substituting the vowel [e] for the vowel [a] or [i] as in "reinfall" for "rainfall". This may be due to pronunciation errors, as the majority of Arab EFL students face difficulties in distinguishing between the English vowel sounds. This is because there are major differences between English and Arabic vowel systems. As for consonant errors, most of them are related to substituting the consonant [b] for [p], e.g. "brefer" for "prefer", [k] for [c], e.g. "tobik" for "topic", and [s] for [c], e.g. "sity" for "city". These findings are in agreement with Al Harrasi (2012) who presents an analysis of the spelling errors made by Omani second-cycle learners.

As mentioned above, most cases of consonant substitution errors are concerned with substituting $[\mathrm{b}]$ for $[\mathrm{p}]$, $[\mathrm{k}]$ for [c], and [s] for [c]. As pointed out by Al Harrasi (2012), the substitution of [b] for [p] most likely occurs because the Arabic sound system does not have the voiceless bilabial plosive /p/, and so Arab students tend to substitute it with the counterpart sound $/ \mathrm{b}$ / (a voiced bilabial plosive), as they do not discriminate between both phonemes. As for substituting $[\mathrm{k}]$ for $[\mathrm{c}]$ and $[\mathrm{s}]$ for [c], this is basically due to the fact that two letters can be used to represent one sound and this case does not exist in the Arabic writing system. Thus, the letters [k] and [c] are used to represent the voiceless velar plosive $/ \mathrm{k} /$, while $[\mathrm{s}]$ and $[\mathrm{c}]$ are used to represent the voiceless alveolar fricative /s/. This, according to Al-Bereiki and Al-Mekhlafi (2016), refers to the fact that the sound-letter correspondence in English is not regular.

\subsubsection{Errors of Insertion}

It has been noticed that all errors in this type are related to vowels. Students normally insert vowels in the middle or final position of words. This type of error comes third among all types of spelling errors, where 22 students out of the total 93 students (i.e., 23.6\%) have made this type of error.

\subsubsection{Errors of Transposition}

Errors of transposition are the least frequent spelling errors in the current study (with only 6 students scoring $6.45 \%)$. In this type normally two letters are misordered. It has been noticed that the misordering of the vowels [ie] was the most frequent error of transposition.

It should be noted that sometimes two or more types of spelling errors are found in one word. For example, the word "obesity" has been misspelled as "obistey". In this case we can observe three types of spelling errors: substitution ([i] for [e]), omission ([i] after [s] is deleted) and insertion ([e] is inserted before [y]). Similarly, the word "topic" is misspelled as "tobaik". Here two types of error can be noticed: substitution ([b] for $[\mathrm{p}]$ and $[\mathrm{k}]$ for $[\mathrm{c}])$ and insertion ([a] is inserted before [i]).

\subsection{Grammatical Errors}

Now the researchers will discuss the types of grammatical errors the students made in their writing. The following table lists these errors in order based on their frequency. 
Table 3. Examples for different types of grammatical errors

\begin{tabular}{|c|c|c|c|}
\hline Error Type & Error Identification & Error Correction & Explanation \\
\hline $\begin{array}{l}\text { Verb Tense } \\
\text { and Form }\end{array}$ & $\begin{array}{l}\text { (1) The governments should } \\
\text { given them all rights. } \\
\text { (2) There many schools in city. } \\
\text { (3) I am prefer to live in the } \\
\text { city. }\end{array}$ & $\begin{array}{l}\text { (1) The governments should } \\
\text { give them all rights. } \\
\text { (2) There are many schools } \\
\text { in the city. } \\
\text { (3) I prefer to live in the city. }\end{array}$ & $\begin{array}{l}\text { (1) The past participle of the verb "give" is used } \\
\text { wrongly instead of the infinitive form. } \\
\text { (2) The verb to be "are" is omitted in this sentence. } \\
\text { (3) In this example the verb to be "am" is wrongly } \\
\text { inserted before the main verb. }\end{array}$ \\
\hline Plurality & $\begin{array}{l}\text { (1) Two main category } \\
\text { (2) This things }\end{array}$ & $\begin{array}{l}\text { (1) Two main categories } \\
\text { (2) These things }\end{array}$ & $\begin{array}{l}\text { (1) The word "category" is not used in the plural } \\
\text { form, though it refers to two items. } \\
\text { (2) The singular demonstrative pronoun "this" is } \\
\text { wrongly used in place of the plural demonstrative } \\
\text { pronoun "these" }\end{array}$ \\
\hline $\begin{array}{l}\text { Subject/Verb } \\
\text { Agreement }\end{array}$ & $\begin{array}{l}\text { Salalah and Muscat has some } \\
\text { similarities }\end{array}$ & $\begin{array}{l}\text { Salalah and Muscat have } \\
\text { some similarities }\end{array}$ & $\begin{array}{l}\text { The singular verb "has" is wrongly used instead of } \\
\text { "have" which is used with plural nouns, since the } \\
\text { subject consists of two nouns. }\end{array}$ \\
\hline Prepositions & $\begin{array}{l}\text { (1) Effect in your body } \\
\text { (2) Between of them }\end{array}$ & $\begin{array}{l}\text { (1) Effect on your body } \\
\text { (2) Between them }\end{array}$ & $\begin{array}{l}\text { (1) In the first example the preposition "in" is used } \\
\text { instead of the preposition "on" which collocates with } \\
\text { the noun "effect". } \\
\text { (2) In the second example the preposition "of" was } \\
\text { wrongly inserted after the preposition "between". }\end{array}$ \\
\hline Part-of-speech & $\begin{array}{l}\text { There are some differents } \\
\text { between Salalah and Muscat }\end{array}$ & $\begin{array}{l}\text { There are some differences } \\
\text { between Salalah and Muscat }\end{array}$ & $\begin{array}{l}\text { The adjective "different" is wrongly used instead of } \\
\text { the noun "difference". }\end{array}$ \\
\hline Word Order & $\begin{array}{l}\text { (1) Hospital many } \\
\text { (2) Small shops traditional } \\
\text { (3) There are in Muscat and } \\
\text { Salalah universities }\end{array}$ & $\begin{array}{l}\text { (1) Many hospitals } \\
\text { (2) Small traditional shops } \\
\text { (3) There are universities in } \\
\text { Muscat and Salalah }\end{array}$ & $\begin{array}{l}\text { In the first two examples the noun phrases are } \\
\text { misordered, where adjectives wrongly come after } \\
\text { nouns. As for the third example, the subject } \\
\text { "universities" is wrongly used after the prepositional } \\
\text { phrase "in Muscat and Salalah". }\end{array}$ \\
\hline Articles & $\begin{array}{l}\text { (1) A big cities } \\
\text { (2) Education system is a same } \\
\text { in both of them. }\end{array}$ & $\begin{array}{l}\text { (1) Big cities } \\
\text { (2) Education system is the } \\
\text { same in both of them. }\end{array}$ & $\begin{array}{l}\text { In the first example the indefinite article "a" is } \\
\text { wrongly used before a plural noun. Here a zero } \\
\text { article should be used. In the second example the } \\
\text { indefinite article is used wrongly instead of the } \\
\text { definite article "the". }\end{array}$ \\
\hline $\begin{array}{l}\text { Adjective } \\
\text { Form }\end{array}$ & $\begin{array}{l}\text { (1) More warm } \\
\text { (2) More cleaner } \\
\text { (3) Very best }\end{array}$ & $\begin{array}{l}\text { (1) Warmer } \\
\text { (2) Cleaner } \\
\text { (3) Very good }\end{array}$ & $\begin{array}{l}\text { The comparative form of the adjective is wrongly } \\
\text { used in the first two examples. In the third example } \\
\text { the superlative form is wrongly used in place of the } \\
\text { positive form of the adjective. }\end{array}$ \\
\hline
\end{tabular}

Having discussed the different types of writing errors made by Omani students at Dhofar University, it became clear that the results of the analysis are consistent with previous studies on investigating Arab students' writing errors (e.g., Al Harrasi, 2012; Sawalmeh, 2013; Younes \& Albalawi, 2015)

Based on the results of the current study, the researchers present a number of suggestions for possible remedies for writing errors. These are summarized as follows:

- Common errors should be corrected by teachers on time and in a clear way through showing students the right forms and structures.

- Teachers should encourage students to discover their mistakes themselves and attempt to correct them through rewriting words and sentences accurately.

- Adopting various teaching methods and strategies that focus on active learning in such a way that suits the abilities and potentials of learners.

- Technological devices should be made available to teachers so that they could help them in accurately presenting the teaching materials to students.

- Teachers should give students intensive exercises and homework assignments that test their language skills.

- Providing students with a stimuli-rich learning environment to motivate them to learn and attempt to overcome the challenges they face.

- Collecting the most difficult words and structures that most students write wrongly and rewriting them correctly on the board in the class. 
In that way students could have more focused training on writing and their writing errors could be addressed so as to avoid them in their future writings. Thus, the third research question has been answered.

\section{Conclusion}

The present study has discussed the common writing errors made by EFL students at Dhofar University in the Sultanate of Oman. The study focused mainly on the spelling and grammatical errors, as these errors have been found to be the most common. The study has found that the grammatical errors account for the biggest number of errors in the Omani EFL students' writing samples. These grammatical errors have been classified into eight different types which are ranked as follows: verb tense and form, plurality, subject/verb agreement, prepositions, part-of-speech, word order, articles and adjective form. The biggest number of errors is thus related to verb tense and form, where $46.23 \%$ of EFL students at Dhofar University have been found to make errors in the use of verbs. Spelling errors, on the other hand, are classified into four different types according to Cook's (1999) classification. These types are omission, substitution, insertion and transposition. The most common type of spelling errors is omission, which accounts for $69.9 \%$ of the total number of EFL students. The study also attempted to uncover the sources of these spelling errors. It found that the EFL learners' spelling errors are generally caused by the differences between the pronunciation and spelling of English words. Generally speaking, most of the students' errors can be attributed to the mother language (L1) interference. According to Sawalmeh (2013), the influence of Arabic on the students' English writing indicates that English language teachers need to take account of the interference of the learners' (L1) or mother tongue in their written or spoken production. Thus, as outlined above, teachers should encourage students to discover their errors themselves and attempt to correct them. This, in turn, will help students to avoid such errors in their future writings.

Given the results of the current study, a number of recommendations for further research are suggested as follows. First, it is recommended that further research be conducted to investigate the EFL students' lexical errors such as synonymy and collocations. Second, the current study aimed to investigate the writing errors of EFL students (males and females) at Dhofar University in Oman. It did not focus on the differences between male and female students. It would be interesting to consider the gender factor and investigate the differences between male and female students in the errors they make in their writings. Third, other research efforts could be made to discuss different types of punctuation errors. Finally, the present study focused on investigating the common errors for first-year students in a university requirement course of basic academic English. Future research could be carried out on investigating the common writing errors made by students majoring in English.

\section{References}

Abu Rass, R. (2015). Challenges Face Arab Students in Writing Well-Developed Paragraphs in English. English Language Teaching, 8(10), 49-59.

Al-Bereiki, S. A., \& Al-Mekhlafi, A. M. (2016). Spelling Errors of Omani EFL Students: Causes and Remedies. Journal of Applied Linguistics and Language Research, 3(7), 20-46.

Al-Busaidi, S., \& Al-Saqqaf, A. H. (2015). English Spelling Errors Made by Arabic-Speaking Students. English Language Teaching, 8(7) 181-199. https://doi.org/10.5539/elt.v8n7p181

Alhaisoni, E. M., Al-Zuoud, K. M., \& Gaudel, D. R. (2015). Analysis of Spelling Errors of Saudi Beginner Learners of English Enrolled in an Intensive English Language Program. English Language Teaching, 8(3), 185-192. https://doi.org/10.5539/elt.v8n3p185

Al Harrasi, K. T. S. (2012). The Most Common Spelling Errors among Omani Learners. Arab World English Journal (AWEJ), 3(2), 96-116.

Alhaysony, M. (2012) An Analysis of Article Errors among Saudi Female EFL Students: A Case Study. Asian Social Science, 8(12), 55-66. https://doi.org/10.5539/ass.v8n12p55

Al Jayousi, M. T. (2011). Spelling Errors of Arab Students: Types, Causes and Teachers'Responses. Unpublished MA Dissertation, American University of Sharjah, UAE.

Brown, H. D. (2007). Principles of Language Learning and Teaching. White Plains, US: Pearson Education.

Cook, V. (1999). Teaching L2 Spelling. Retrieved July 19, 2018, from http://www.viviancook.uk/Writings/Papers/TeachingSpelling.htm

Cook, V. (1997). L2 Users and English Spelling. Journal of Multilingual and Multicultural Development, 18(6), 474-488. https://doi.org/10.1080/01434639708666335

Corder, S. P. (1967). The Significance of Learners' Errors. International Review of Applied Linguistics in 
Language Teaching, 5(4), 161-170.

Hasbún, L. (2007). Fossilization and Acquisition: A Study of Learner Language. Filología y Lingüistica, 33(1), $113-129$.

Hourani, T. M. Y. (2008). An Analysis of the Common Grammatical Errors in the English Writing made by $3^{\text {rd }}$ Secondary Male Students in the Eastern Coast of the UAE. Unpublished MA dissertation, Institute of Education, British University in Dubai, UAE.

James, C. (2013). Errors in Language Learning and Use: Exploring Error Analysis. Routledge. https://doi.org/10.4324/9781315842912

Kharma, N., \& Hajjaj, A. (1997). Errors in English among Arabic Speakers: Analysis and Remedy. Beirut: Librairie du Liban.

Khuwaileh, A. A., \& Al Shoumali. (2000). Writing Errors: A Study of the Writing Ability of the Arab Learners of Academic English and Arabic at University. Language, Culture, Curriculum, 13(2), 174-183. https://doi.org/10.1080/07908310008666597

Kocatepe, M. (2017). Female Arab EFL Students Learning Autonomously Beyond the Language Classroom. English Language Teaching, 10(5), 104. https://doi.org/10.5539/elt.v10n5p104

Murad, T. M., \& Khalil, M. H. (2015). Analysis of Errors in English Writings Committed by Arab First-year College Students of EFL in Israel. Journal of Language Teaching and Research, 6(3), 475-481. https://doi.org/10.17507/j1tr.0603.02

Naif, A. H., \& Saad, N. S. (2017). Language Learning Strategies Use and Challenges Faced by Adult Arab Learners of Finnish as a Second Language in Finland. English Language Teaching, 10(4), 111-126. https://doi.org/10.5539/elt.v10n4p111

Norrish, J. (1983). Language Learners and Their Errors. London: Macmillan Press.

Qaid, Y. A., \& Ramamoorthy, L. (2011). Analysis of Intralingual Errors in Learning English as a Foreign Language by Yemeni Students. Language in India, 11(5), 534-545.

Rimbar, H. (2017). The Influence of Spell-Checkers on Students' Ability to Generate Repairs of Spelling Errors. Journal of Nusantara Studies, 2(1), 1-12. https://doi.org/10.24200/jonus.vol2iss1pp1-12

Salem, M. S. A. S. (2007). The Effect of Journal Writing on Written Performance, Writing Apprehension, and Attitudes of Egyptian English Majors. Unpublished doctoral dissertation, The Graduate School, College of Education, The Pennsylvania State University

Sawalmeh, M. H. (2013). Error Analysis of Written English Essays: The Case of Students of the Preparatory Year Program in Saudi Arabia. English for Specific Purposes World, 40(14), 1-17.

Ulijn, J. M., \& Strother, J. B. (1995). The Speaking and Writing Processes, In J. M. Ulijn \& J. B. Strother (Eds.), Communicating in Business and Technology: From Psycholinguistic Theory to International Practice (pp. 153-179). New York/Frankfurt: Lang.

Younes, Z. B., \& Albalawi, F. S. (2015). Exploring the Most Common Types of Writing Problems among English Language and Translation Major Sophomore Female Students at Tabuk University. Asian Journal of Basic and Applied Sciences, 3(2), 7-26.

\section{Copyrights}

Copyright for this article is retained by the author(s), with first publication rights granted to the journal.

This is an open-access article distributed under the terms and conditions of the Creative Commons Attribution license (http://creativecommons.org/licenses/by/4.0/). 